\title{
The Effectiveness of Puppet Papers and Board Games Against Reproductive Health Education of Children With Special Needs
}

\author{
Masrul $^{1}$, Yulizawati ${ }^{2}$, Rika Susanti ${ }^{3}$, Siska Bradinda Putri Sudirman ${ }^{2}$, Rahmi Yulyanti $^{2}$, Filda $^{2}$ \\ masrulmuchtar@med.unand.ac.id \\ ${ }^{1}$ Department of Nutrition, Faculty of Medicine, Universitas Andalas Padang, Indonesia \\ ${ }^{2}$ Bachelor of Midwifery Program Faculty of Medicine Andalas University Jln. Niaga no. 56 Padang, \\ Indonesia \\ ${ }^{3}$ Division of Forensic and Medicolegal, Faculty of Medicine, Andalas University, Padang
}

\begin{abstract}
Reproductive health is a right of everyone especially children and teenagers to be given information and access to reproductive health and sexuality education is right for children with special needs. But the fact is that reproductive health education for children with special needs is rarely given attention because of the limitations they have, so the problem of sexual abuse and sexual assaults on children with special needs is still a major problem in Indonesia. The method is designed using paper puppet media and board games, supported by data collection form of pretest and posttest questionnaire on children with special needs with the aim of increasing the knowledge of children with special needs about the importance of understanding of reproductive health education and applying it correctly. The analysis was carried out by the Wilcolxon Signed Ranks Test, it was stated that there was a significant relationship if $\mathrm{p}<0.05$. This program succeeded in increasing the knowledge of children with special needs known through the Wilcolxon Signed Ranks Test there was a significant difference between pre test and post test, $\mathrm{P}=0.005$ ( $\mathrm{P}<0.05$ ). Thus, it can be concluded that the provision of information about reproductive health is related to the level of knowledge of children with special needs, a significant increase in knowledge occurs.
\end{abstract}

Keywords: Effectiveness, Games, Reproductive Health

\section{Introduction}

Today, deviant sexuality behavior that leads to a number of incidents of harassment and sexual violence in children with special needs is a serious problem to consider. According to the Washington Coalition of Sexual Assault Programs in Widyaputri (2017), women with disabilities are more likely to experience domestic violence as much as $37.3 \%$ compared to women in general as much as $20.6 \%$. Women with these limitations, as well as more about the behavior of dark record of unwanted sexuality of $19.7 \%$ over other women as much as $8.2 \%$. In addition, as much as $80 \%$ women and $30 \%$ men with intellectual disability experience sexual violence. And, $50 \%$ of the women who have experienced sexual violence, experienced it more than ten times (Andriana, D. 2011)

About $15 \%$ of the world's population are persons with disabilities and $82 \%$ of them are in developing countries which generally experience limitations, especially in health and education. The total population in Indonesia is 237,641,326 people, an estimated $10 \%$ (24 million) of people are with special needs (Badan Pusat Statistik, SAKERNAS 2011). 
The number of people with disabilities in Indonesia is $11,580,117$ people including 3,474,035 (visual disability), 3,010,830 (physical disability), 2,547,626 (hearing disability), $1,389,614$ (mental disability) and 1,158,012 (chronic disability). This figure shows that there was a significant increase in the number of people with disabilities in one year. (Kementerian Sosial, 2010. PUSDATIN)

This is explained in the ACT 20 years Number of RI 2003 article 5 paragraph 2 States that every citizen who has a physical, mental disorders, intellectual, social, and emotional reserves the right to obtain education. Then in a copy of the regulation of the Minister of national education Indonesia Number 70 was also mentioned that the learners who have abnormalities of physical, emotional, mental, social and or have the potential of special talent or intelligence and the need to get educational services that are appropriate to their needs (Davis, Beverly and M. Summers. 2015)

Based on the above background, an innovation was designed to teach something called paper puppets and board games by utilizing the audio-visual demonstration function and teamwork on SLB students which by utilizing this function can make it easier for students to absorb something so that it can improve their understanding. (Rahadi Aristo (2004: 56).

The role of media in learning methods is very important and needed to support the provision of information provided so that it must be packaged as attractive as possible so that it can attract the attention of students with special needs at YPPLB Padang.

Based on the large Indonesian Language Dictionary in the Yasasusastra (2011), Wayang is an imitation doll of leather, wood carvings and so on that can be used to portray characters in traditional drama performances. The information provided in the puppet show presented by either utilizing audiovisual audience. While board games are a medium for delivering information in the form of card stacking games that utilize the function of fine motoric activity of students with special needs. (Andriana, 2011).

Both are one of the latest innovations that are effective in developing an analysis of students with special needs about their reproductive health.

\section{Methods}

This activity was carried out in schools of children with special needs YPPLB Padang for 4 meetings with a series of activities:

a. Preparation phase

Activities carried out in the preparation stage are:

1. Survey to the location of the activity

2. Formation of friends with special needs children. In the early stages, a team of "children with special needs" was formed through a pamphlet to facilitate friends out there who want to feel the atmosphere and get in touch with children with special needs. Administration and licensing of community services

3. Search for educational videos, making pre-test and pro-test questionnaires, making wayang product designs (puppet frames, puppet characters, DVDs)

4. Designing a book about reproductive health.

b. Activity Implementation Phase

Service activities will be carried out after the preparation phase is complete. The activity will be carried out in schools of children with special needs YPPLB Padang for 1 month with 4 meetings.

1. Introduction and Self Concept Games

Introduction 
It was preceded by the opening ceremony and continued with an introduction. Then, the first educational video is shown, there are two animated videos that can be easily understood. On the sidelines of the video, a question and answer session was conducted to see how understanding children with special needs about the material displayed.

Self concept games

Games that aim to recognize their self-concept from an early age. Game technical; dividing students into two groups and preparing two basins in which there are game cards / things that women and men like in random situations. Then, students are asked to line up while taking the cards they like. The desired output from this game is that male students can take picture cards containing games.

2. Drawing and Telling

This activity was carried out in the second meeting, where before starting the activity the team conducted a review of the material of the first meeting by giving flyers made as interesting as possible. The activities of "Drawing and Telling" as a form of entertainment for children with special needs while knowing the extent to which they know about the material to be taught. Technically, the team provided pictures related to the material taught by self-defense and coloring, and children with special needs from YPPLB Padang were asked to color, understand and ask them to share the pictures obtained.

3. Preliminary data collection (Pretest)

Preliminary data collection using a questionnaire to determine the initial level of knowledge of children with special needs YPPLB Padang.

4. WKBG method

Paper puppets

Wayang is made as attractive as possible, and presents \pm 10 characters in it according to their respective roles. The character played an appropriate role as an illustration of reproductive health education, such as how to dress, the game played, how to take care of themselves, the right attitude with the opposite sex, and how to reduce anxiety in these children during puberty the first time, both in men and woman. The voice filler is carried out by the team by means of dubbing so that a clear and clear sound can be produced as well as a number of supporting sound effects. In this paper puppet show, the team presented JBI (Sign Language Interpreters), this meant that all performances could be enjoyed by all children with special needs in Padang YPPLB, including even deaf children. This media utilizes audio-visual functions and demonstrations so that the material provided can be easily captured by children with special needs (Yasasusastra, Syahban. 2011).

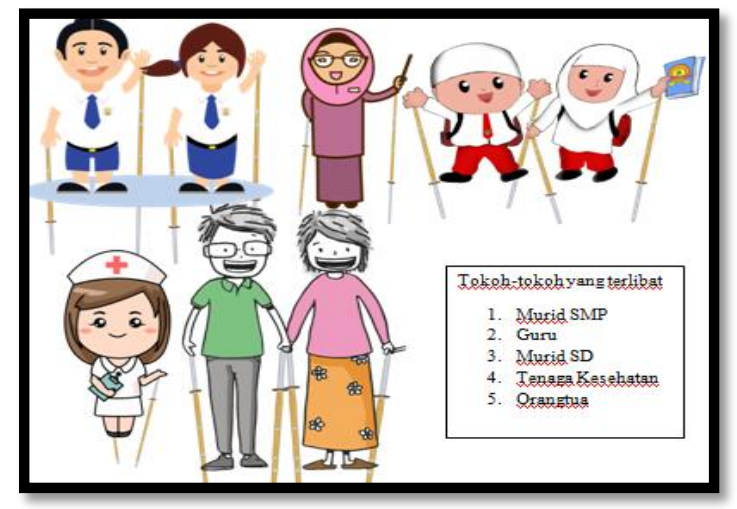

Figure 1. Paper Puppets 
Board games

Board games are card games and letter puzzles that are combined into one. The card contains questions about reproductive health education that has been taught. Meanwhile, letter puzzle is a collection of letters that are distributed to each group of children with special needs YPPLB Padang randomly and will later be assembled into an answer to the question given. This board game is played by all Padang YPPLB special needs children who participate in this reproductive health activity from the beginning.

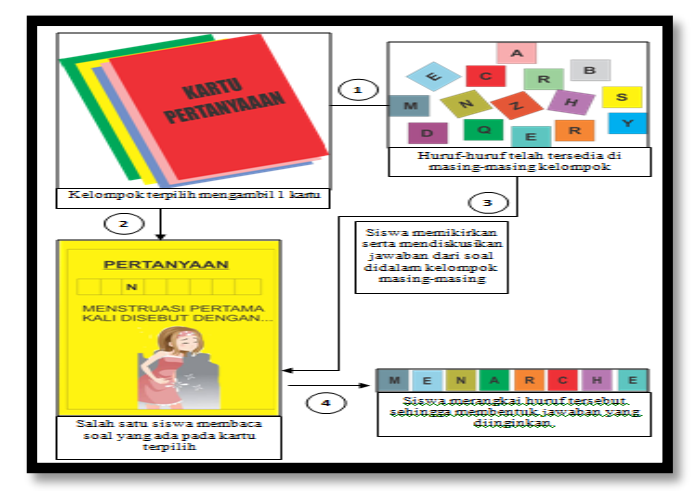

Figure 2. Board Scheme

5. Final data collection (posttest)

Taking the final data using the same questionnaire as the first one for children with special needs aims to find out whether there is an increase in understanding regarding reproductive health education

6. Monitoring and evaluation

Aim to see the development of the dedication that has been given. In the implementation of this program, it is known whether there are obstacles and solutions. So, this program can run smoothly and is useful for children with special needs. This activity is carried out at the end of each series of activities provided.

\section{RESULT}

The implementation of PKM-M "The Effectiveness of the Use of Paper Puppets and Board Games in Providing Comprehensive Reproductive Health Education for Children with Special Needs YPPLB Padang" has gone well. All design activities that have been made are carried out in accordance with the time and place specified. In carrying out all activities, an evaluation is always carried out to assess whether the activity is effectively implemented or not. The activities carried out for approximately 1 month with $4 \mathrm{x}$ this meeting involved approximately 40 children with special needs. The results achieved included the formation of SLB friends, a set of puppet papers, reproductive health books, wayang dvd, published articles on print and electronic media. The first step taken is to survey the location to find out what kind of reproductive health problems are in the school and the effective ways that can be used. Then, forming a "Sahabat SLB", from the distributed pamphlets there were 17 SLB friends, who participated with the team in direct interaction with children with special needs YPPLB Padang and this was a forerunner to the formation of a SLB friendly community in Padang City. Positive responses are obtained directly from parents and teachers regarding the given puppet shows and board games, 
remembering these creative and innovative ways that are needed by students today. Preparations for the activities were assessed to have been carried out $100 \%$ of the timeline that had been prepared.

Table 1. Results of Achievement Evaluation for Activity Preparation Phase

\begin{tabular}{clcc}
\hline No & \multicolumn{1}{c}{ Activities } & \multicolumn{2}{c}{$\mathbf{1 0 0 \%}$ achievement } \\
\cline { 3 - 4 } & & Implemented & $\begin{array}{c}\text { Not } \\
\text { Implemented }\end{array}$ \\
\hline 1. & Survey on the location of activities & $100 \%$ & - \\
2. & Formation of SLB friends & $100 \%$ & - \\
3. & $\begin{array}{l}\text { Administration of licensing and } \\
\text { licensing of community services }\end{array}$ & $100 \%$ & - \\
4. & $\begin{array}{l}\text { Search for materials about } \\
\text { reproductive health }\end{array}$ & $100 \%$ & - \\
5. & $\begin{array}{l}\text { Making design about reproductive } \\
\text { health }\end{array}$ & $100 \%$ & - \\
\hline \multicolumn{2}{l}{ Achievement of the activity preparation stage } & $100 \%$ & - \\
\hline
\end{tabular}

Table 2. Wilcoxon Signed Rank Test Test Results on Pretest and Postest Questionnaires

Postest - Pretest

$\mathbf{Z}$

$-2.820^{\mathrm{a}}$

Asymp. Sig. (2-tailed)

.005

Based on table 2. the result of Wilcoxon test (pretest-posttest) was obtained by Asymp. Sig. (2-tailed) is 0.005 less than $<0.05$, so it can be concluded that "Ha is accepted", that is, there is a significant relationship. This result means that the provision of information about reproductive health using paper puppet methods and board games is effective to increase the level of knowledge. children with special needs about reproductive health.

Table 3. Results of Pretest and Posttest Questionnaire Data Analysis

\begin{tabular}{lccrrr}
\hline \multicolumn{7}{c}{ Descriptive Statistics } \\
\hline Pretest & N & Mean & \multicolumn{1}{c}{ Std. Deviation } & \multicolumn{1}{c}{ Minimum } & \multicolumn{1}{c}{ Maximum } \\
\cline { 2 - 7 } Posttest & 19 & 4.1053 & .93659 & 2.00 & 5.00 \\
\hline
\end{tabular}

Based on table 3. shows that the average value of pretest before counseling was 4.10 , while after counseling the posttest average score was 5.15 . This means that the average posttest value is greater than the initial value. This difference in value is significant, so it can be said that the provision of counseling using paper puppet methods and board games can increase the knowledge of children with special needs about reproductive health.

\section{Discussion}

According to Edgar Dale, the use of learning media often uses the Cone of Experience principle, which requires media such as textbooks, learning materials, and some moving objects. Dale illustrates that utilizing the "audio-visual" function can improve understanding by $20 \%$, 
"demonstration" by $30 \%$ and "practice doing" by $75 \%$ which has been applied to paper puppet media and board games (Davis et al, 2014).

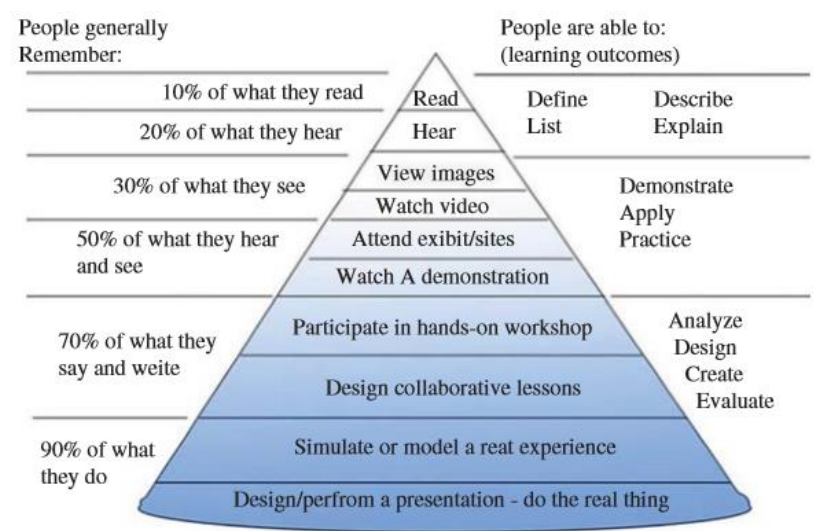

Figure 3. Cone of Experience

During the activity, all documentation has been published on social media and other print media. Through this activity, also produced a video puppet that has been stored in DVDs and reproductive health books that are currently in the management of IPR (Intellectual Property Rights). Broadly speaking, this program has great sustainability potential. The sustainability of this program can be ascertained through 1 set of puppets and reproductive health books provided. In addition, the initiation of the SLB friends community is certainly a community that is very useful later in accommodating children with special needs in gaining new knowledge about what they do not know, given that such communities are still very minimal in Padang City.

\section{Conclusion}

There is an increase in knowledge known through the Wicolxon Signed Ranks Test. There is a significant difference between pre test and post test, $\mathrm{P}=0.005(\mathrm{P}<0.05)$. Thus, it can be concluded that the provision of information about reproductive health is related to the level of knowledge of children with special needs, a significant increase in knowledge occurs. The availability of learning materials for teachers in the form of a puppet paper set, wayang dvd containing recordings, and reproductive health books to be used as learning material in schools. Activities like this must continue, because reproductive health is the responsibility of each individual, including children with special needs.

\section{References}

Andriana, D. 2011. Tumbuh Kembang \& Terapi Bermain Pada Anak. Jakarta: Salemba Medika. Badan Pusat Statistik. 2011. Survey Angkatan Kerja Nasional. Jakarta: Badan Pusat Statistik. Kementrian Sosial. 2010. Pusat Data dan Informasi. Jakarta: Kemensos RI.

Davis, Beverly and M. Summers. 2015. Applying Dale's Cone of Experience to increase learning and retention: A study of student learning in a foundational leadership course. QScience Proceeding Engineering Leaders Conference2014 (6) : 1-7.

Rahadi, Aristo. 2004. Media Pembelajaran. Jakarta: Departemen Pendidikan Nasional. Yasasusastra, Syahban. 2011. Mengenal Tokoh Pewayangan. Surakarta : Pustaka Mahardika 